\title{
17. The Advent of Two New Micro Parties: The Palmer United Party and Katter's Australia Party
}

\author{
Tom King
}

This chapter provides an analysis of the performance of the Palmer United Party (PUP) and Katter's Australia Party (KAP) at the 2013 federal election in terms of the number of candidates fielded and the overall results nationally and in each state. The chapter analyses the swings these micro parties received and examines where their votes appeared to come from. This entails analysing which major party or parties had swings against them that saw votes flow to either KAP or PUP. This chapter concludes that Palmer's fledgling party performed far better collectively than the KAP candidates who were led by an experienced sitting federal politician who had secured additional state seats in the Queensland assembly. The analysis suggests that swings to both these micro parties were regionally sensitive and came not from any one party but from a number of other established parties. While the swing varied among electorates, as a general rule the two parties performed better in rural electorates than in urban electorates.

\section{The parties and their leaders}

Key (1964: 254ff) has categorised minor parties into three groupings: secessionist (parties which form when there is a split in an established party and one section of the party breaks away to form a 'purer' version of the original party); aggrieved minority (parties with mainly economic interests but which may have other or even alternative interests; they form because of some resentment regarding these interests); and doctrinal (parties which promote a particular doctrine both in and out of season, for example, communist, socialist or neo-nazi parties, and perhaps even environmentalist parties).

Both KAP and PUP could be classified as both secessionist and aggrieved minorities. They were effectively breakaway micro parties from the existing conservative side of politics, mobilised by well-known personalities who are in their own way charismatic individuals who have gained some respect and a following from a group or groups of voters. In the past there have been many other well-known celebrity personalities who have founded and led minor or 
micro parties, for example, Vince Gair and the Democratic Labor Party, Gordon Barton and the Australia Party, Don Chipp and the Australian Democrats, Bob Brown and the Australian Greens, as well as Pauline Hanson and One Nation.

\section{Katter's Australia Party}

In the case of Bob Katter and the KAP, his grievances were over the policy directions of the National Party that accommodated economic policies favouring market forces at the expense of the financial viability of farmers and small business people. The party was belatedly formed by Katter who, as an existing member of the House of Representatives and a well-known political maverick, had been content to sit on the sidelines of the party system. He had entered the Queensland parliament in 1974 as a Country Party/National Party member rising to become a state minister under the Bjelke-Petersen regime. From 1993 to 2001 he was a troublesome member of the federal parliamentary National Party. In 2001 he resigned from the National Party to sit as an independent because he perceived the Nationals had deserted farmers and small business people in regional Australia. In September 2011 he formed Katter's Australia Party, registering it at both state and federal levels. In 2012 he compiled a book (Katter 2012) which, in addition to providing his personal version of Australian history, attempted to spell out what his new party stood for. Nowra (2013: 28) comments that 'there is raw appeal in his [Katter's] refusal, unlike Julia Gillard or Tony Abbott, to resort to weasel words or hide his own true beliefs.' In other words, Katter is a plain-speaking person and an upfront politician.

Going into the federal election, KAP could boast three members in the Queensland state parliament. In the 2012 state election, Katter's son Rob won the electorate of Mount Isa with 41.61 per cent of the primary vote. Shane Knuth, a former National Party state MP won Dalrymple for KAP with 53.73 per cent of the primary vote. Knuth is the brother of the former One Nation MP, Jeff Knuth. Ray Hopper, also an ex-Nationals member, won Condamine with 58.3 per cent of the primary vote as a Liberal National Party (LNP) MP but resigned from that party in late 2012 to join Katter's new party. All three of those electorates are classified as rural electorates.

Katter was re-elected at the 2013 election but suffered a significant swing against him. Katter was the only candidate from his party to be elected. Ultimately, the advantages of incumbency as a highly-recognisable sitting member of parliament, and with three sitting members of state parliament adding to his profile, did not actually provide much of an advantage to Katter and his party. His decision to preference the Labor Party in the Senate may have also cost his party support in the primary vote. 
In fact in the lead-up to the campaign, and indeed throughout the campaign, Katter and his party became heavily embroiled in a relatively marginal issue for his old-style conservative constituency that would only damage their populist support, namely the same-sex marriage debate. Katter had stated at a public pro-marriage rally in August 2011 that 'same-sex marriage should not be taken seriously and deserves to be ridiculed' (Sadler 2011). But matters came to a head when KAP endorsed country singer James Blundell as the party's lead Senate candidate in Queensland. In his first public speech as candidate, Blundell announced that he would vote in favour of gay marriage and, for good measure, also advocated the abolition of penalty rates. This enraged some of the party's backers in the Electrical Trades Union. Blundell's statement on same-sex marriage 'flabbergasted the socially conservative party faithful' and 'the exodus of party members accelerated after Blundell's comments' (Houghton 2013).

A number of members of KAP either resigned or were expelled from the party over their views or comments regarding same-sex marriage. Among those expelled were the party's candidate in Wannon, Tess Corbett, and Queensland Senate candidate hopeful Bernard Gaynor. Gaynor was the National General Secretary of the party, a married father of five children and a former officer in the Australian Army. Gaynor enjoyed a high profile and was forthright in his views against same-sex marriage. The dismissal of Gaynor as a candidate with its resultant adverse publicity was another reason for the party's poor showing at the election as it showed the party to be divided and unsure of its position on same-sex marriage.

Katter, in spite of his years in parliament, was very negligent in laying down the rules and procedures for preselecting candidates for the party. Nowra (2013: 31) observes that:

Like Pauline Hanson's One Nation party before it, the KAP attracts ratbags, the undistinguished and the plain daffy. Evidently, the KAP's selection process lacks rigour. Katter doesn't seem to be strongly in charge of his own party, but more than that, he doesn't seem to care particularly that he's not.

Katter's new party stands for the same range of protectionist economic issues that Pauline Hanson and One Nation championed, but without any racist overtones. McDonnell (2001: 6) describes Katter as 'an old fashioned protectionist' who is not racist 'and cannot be described as one.' McDonnell goes on to say that 'he is therefore a potential stain free rallying point for ageing conservatives of the right who are turned off Pauline Hanson ... [and] who are turned off political parties in general'. 


\section{The Palmer United Party}

The Palmer United Party is led by Clive Palmer, a flamboyant and well-known political identity in Queensland with a commanding presence. He is a high profile businessman and operates a number of business interests which include mining and tourism. He had been a major financial backer of the conservative parties in Queensland, but fell out with the LNP and especially with the Newman State Government, and so set up his own political party. The party's major concern is the mining industry in Australia and the reduction of red tape for that industry. It supports the abolition of the carbon tax as well as the mining tax. The party also supports free tertiary education and swift on-shore processing of asylum seekers, after allowing them to fly to Australia. Genuine asylum seekers would be allowed to stay in Australia and take up employment and have access to welfare (PUP 2013).

The PUP opted for a tactical advantage on the same-sex marriage issue by declaring in its policies that social issues such as same-sex marriage would be a matter for a conscience vote from the party's parliamentary members. In a press release dated 30 July 2013, Clive Palmer advised that the PUP believes issues such as same-sex marriage, the abortion debate and euthanasia should all come down to the candidates' individual position on the issue. Palmer concluded by saying that:

the Palmer United Party is committed to offering a voice to all Australians, which is why we promote the individual rights of everyone. There will be no party pressure on any of our candidates and we will respect their thoughts, views and ideas on all social issues including same-sex marriage (Palmer/PUP 2013).

Palmer himself contested and won the federal electorate of Fairfax on the Queensland Sunshine Coast by a slim margin of just 53 votes. His re-election in three years' time is by no means assured. In addition his fledgling party managed to get two Senators elected for the period 2014-20, with one each from Tasmania and Queensland. Before the recount took place in Western Australia, a third PUP candidate, Zhenya 'Dio' Wang, had initially been elected from that state. The April 2014 re-election for the half-Senate seats in Western Australia, ordered by the Court of Disputed Returns, saw him elected to the Senate.

The PUP suffered a small embarrassment in Western Australia that led to the dis-endorsement of its candidate in the seat of Fremantle for 'not toeing the party line'. The candidate, Teresa van Lieshout, was a feisty, opinionated, 'bornagain' Christian who claimed that the global financial crisis was a typical 'anti- 
Christ' strategy and Hurricane Sandy was God's punishment for globalisation. She was replaced as the PUP candidate by Vashil Vimal Sharma who polled only 3.96 per cent of the primary vote in that seat.

There were claims that the PUP ran an e-campaign over the internet and through social media, and out-spent the other minor parties in the campaign. However, Clive Palmer claimed his party had only spent 'between $\$ 8$ and $\$ 12$ million ... on everything. That would have been established in the party doing everything'. Palmer went on to claim that 'the Liberals would have spent about \$54 million, and Labor probably, you know, not much more than us' ('Palmer Drama' 2013).

\section{The major policies announced by the two parties}

Clive Palmer and the PUP policies included the abolition of the carbon and mining taxes and no increase in other taxes. The party also announced the quick processing of asylum seekers and abolition of tertiary fees and Higher Education Contributions Scheme (HECS) payments.

Bob Katter and the KAP included among their policies a national interest test for the privatisation of any public assets and the provision of an arbitrated price for agricultural produce where farmers request it.

A list of PUP and KAP policies can be found in the appendix to this chapter.

\section{What seats did they contest?}

Table 1: 2013 election, House of Representatives-number of seats contested

\begin{tabular}{|l|r|r|r|}
\hline State & Palmer United Party & Katter's Australia Party & \multicolumn{1}{|l|}{ Total Seats in HoR } \\
\hline National & 150 & 61 & 150 \\
\hline NSW & 48 & 14 & 48 \\
\hline Vic & 37 & 10 & 37 \\
\hline Qld & 30 & 26 & 30 \\
\hline WA & 15 & 7 & 15 \\
\hline SA & 11 & 3 & 11 \\
\hline Tas & 5 & 1 & 5 \\
\hline ACT & 2 & 0 & 2 \\
\hline NT & 2 & 0 & 2 \\
\hline
\end{tabular}

Source: Australian Electoral Commission. 
The PUP contested all 150 electorates in the House of Representatives and fielded Senate candidates in every state and territory. Significantly, while Palmer was wealthy enough to generously fund his party's core campaign, it is truly remarkable that he was able to find people who were able and willing to stand as candidates. By contrast, KAP only contested 40 per cent of the House of Representatives electorates (61 seats) and sometimes struggled to find candidates. The party's choice of seats to contest seems to be without rhyme or reason. For example, they did not contest a number of rural seats such as Farrer in New South Wales, but did stand for the urban electorate of Lilley in Queensland. Surprisingly, while the party contested the Senate in the Australian Capital Territory (not a favourable location), it did not contest the Senate in the Northern Territory where it would have likely done better. This could be because of a lack of finance or a failure to find willing candidates who would stand and make the necessary financial and time commitments. Katter, however, claimed that in the campaign his party 'campaigned all over Australia' but 'we spent no money virtually at all' (Horn 2013). Katter also claimed that 'it's no secret, we had massive disorganisation internally and in relation to the party's finances'. He went on to say in the same report that Clive Palmer's party, which polled strongly, 'was visible all of the time, but we weren't' (Sydney Morning Herald 2013).

Throughout much of the campaign the two new micro parties were largely considered as entertainment value. Yet, public opinion polling tracked a late swing to Palmer's party in the last two weeks of the campaign while Katter's stalled.

\section{The performance of the two parties in the election}

Tables 2 and 3 show the performance of the two parties both nationally and state-by-state for the House of Representatives and the Senate.

Table 2: 2013 election, House of Representatives - total votes and percentage of formal vote

\begin{tabular}{|l|r|r|}
\hline State & Palmer United Party & Katter's Australia Party \\
\hline National & $709,041(5.49 \%)$ & $134,226(1.04 \%)$ \\
\hline NSW & $174,551(4.20 \%)$ & $16,534(0.40 \%)$ \\
\hline Vic & $119,623(3.63 \%)$ & $15,409(0.47 \%)$ \\
\hline Qld & $278,131(11.02 \%)$ & $94,540(3.75 \%)$ \\
\hline WA & $67,332(5.32 \%)$ & $4,997(0.39 \%)$ \\
\hline SA & $37,981(3.78 \%)$ & $2,268(0.23 \%)$ \\
\hline Tas & $20,026(6.06 \%)$ & $478(0.14 \%)$ \\
\hline ACT & $6,788(2.81 \%)$ & 0 \\
\hline NT & $4,609(4.63 \%)$ & 0 \\
\hline
\end{tabular}


The national level of support for Katter was affected by the fact that he stood candidates in only 40 per cent of seats. Significantly, however, except for Queensland (Katter's personal electoral base), the level of support for KAP was below that of its rival micro party in the worst-performing jurisdiction for Palmer (2.81 per cent in the Australian Capital Territory). In only one state did KAP manage to get over 0.5 per cent of the jurisdictional vote. In fact nationally, the PUP won five times the number of votes achieved by KAP, and PUP finished with a national vote of 5.49 per cent-only 3.16 per cent behind the Greens. KAP on the other hand scored a national vote below Family First and well below the combined vote for the Independents (standing 68 candidates).

As can be seen from Table 2, Katter did not stand candidates in either of the two territories and contested only one electorate in Tasmania. By way of contrast, when the Australian Democrats contested their first election in 1977, that minor party scored 9.4 per cent of the vote in the House of Representatives.

Table 3: PUP versus KAP - best results in House of Representatives seats

\begin{tabular}{|l|l|r|l|l|r|}
\hline Palmer United Party & \multicolumn{4}{l|}{ Katter Australia Party } \\
\hline Electorate & State & Per cent & Electorate & State & Per cent \\
\hline Fairfax & Qld & 26.49 & Kennedy & Qld & 29.36 \\
\hline Hinkler & Qld & 17.65 & Herbert & Qld & 8.08 \\
\hline Fisher & Qld & 17.42 & Dawson & Qld & 6.74 \\
\hline McPherson & Qld & 15.92 & Wide Bay & Qld & 5.88 \\
\hline Wide Bay & Qld & 15.88 & Maranoa & Qld & 5.59 \\
\hline Fadden & Qld & 14.67 & Capricornia & Qld & 5.54 \\
\hline Wright & Qld & 14.48 & Wright & Old & 5.37 \\
\hline Maranoa & Qld & 13.91 & Hinkler & Qld & 4.58 \\
\hline Moncrieff & Qld & 13.68 & Leichhardt & Qld & 4.29 \\
\hline Bowman & Qld & 12.71 & Flynn & Qld & 4.13 \\
\hline
\end{tabular}

Source: Australian Electoral Commission.

Significantly, all of the electorates in Table 3-which lists PUP's and KAP's best results - are in Queensland. Katter personally out-polled Palmer-but only just, with 29.36 per cent in Kennedy compared to Palmer's 26.49 per cent in Fairfax. With the exception of Kennedy, Palmer's best electorates received a higher percentage of votes than any of the best Katter electorates. The tenth best Palmer electorate of Bowman captured 12.71 per cent of the vote, compared to the second best Katter electorate of Herbert where KAP only received 8.08 per cent of the vote. In Fairfax and Kennedy, both Katter and Palmer were competing effectively for the same constituency, which affected their respective results. 
Table 4: PUP versus KAP - worst results in House of Representatives seats

\begin{tabular}{|l|l|r|l|l|r|}
\hline Palmer United Party & \multicolumn{4}{l|}{ Katter Australia Party } \\
\hline Electorate & State & Per cent & Electorate & State & Per cent \\
\hline Melbourne & Vic & 0.92 & Reid & NSW & 0.35 \\
\hline Wentworth & NSW & 1.08 & Swan & WA & 0.51 \\
\hline Melb Ports & Vic & 1.38 & Throsby & NSW & 0.56 \\
\hline Sydney & NSW & 1.43 & Hindmarsh & SA & 0.63 \\
\hline Reid & NSW & 1.51 & Banks & NSW & 0.65 \\
\hline Higgins & Vic & 1.59 & Hasluck & WA & 0.66 \\
\hline Kooyong & Vic & 1.60 & Indi & Vic & 0.69 \\
\hline Chisholm & Vic & 1.63 & Griffith & Qld & 0.69 \\
\hline Grayndler & NSW & 1.71 & Franklin & Tas & 0.71 \\
\hline Bennelong & NSW & 1.80 & Makin/Barton & SA/NSW & 0.71 \\
\hline
\end{tabular}

Source: Australian Electoral Commission.

All of Katter's worst electorates scored significantly more poorly than Palmer's worst seat, Melbourne (an urban seat), where PUP achieved a mere 0.92 per cent of the vote. Significantly, one of the electorates where KAP performed worst was Griffith, which is an electorate in Katter's home state of Queensland. In New South Wales, KAP was out-polled by One Nation in four seats: Hume, Lyne, Barton and Werriwa.

Table 5: 2013 election, Senate

\begin{tabular}{|l|r|r|}
\hline State & Palmer United Party & Katter's Australia Party \\
\hline National & $653,089(4.91 \%)$ & $119,550(0.90 \%)$ \\
\hline NSW & $148,281(3.39 \%)$ & $19,101(0.44 \%)$ \\
\hline Vic & $123,889(3.66 \%)$ & $15,525(0.46 \%)$ \\
\hline Qld & $258,994(9.89 \%)$ & $76,918(2.94 \%)$ \\
\hline WA & $59,708(4.94 \%)$ & $3539(0.29 \%)$ \\
\hline SA & $27,484(2.65 \%)$ & $1,666(0.16 \%)$ \\
\hline Tas & $22,184(6.58 \%)$ & $1375(0.41 \%)$ \\
\hline ACT & $5213(2.11 \%)$ & $1416(0.57 \%)$ \\
\hline NT & $7386(7.14 \%)$ & 0 \\
\hline
\end{tabular}

Source: Australian Electoral Commission.

Neither KAP nor PUP polled exceedingly well in the upper house vote. Palmer scored 4.91 per cent to Katter's 0.9 per cent. By way of contrast, in 1977 the Australian Democrats scored 11.1 per cent of the vote in the Senate election. As 
micro parties rather than established minor parties, both PUP and KAP have a state in which they are clearly strongest. In this case, that state is Queensland for both parties. On a percentage basis in Queensland, both parties scored well above the national percentage of votes that they received. In fact, PUP polled well in Fisher and Hinkler, and with a little more support the party could have won those two seats. The 2013 federal election saw a general increase in micro parties, making KAP and PUP two of many aggrieved micro parties in a Melbourne Cup field. In this environment, PUP performed poorest in South Australia, where it was up against high profile minor party candidates such as Family First's Bob Day, and Nick Xenophon. A second point to make is that the vote for KAP in the Senate was a lot smaller than that for the PUP - in New South Wales and Victoria KAP's vote was miniscule.

Comparing the votes for the House of Representatives with those for the Senate for each party, it can be seen that nationally both parties received a higher House vote. This is surprising for minor parties, as they tend to poll higher in the Senate (because voters believe the minor party candidate has a better chance of being elected for the Senate). This is true of the Democratic Labour Party (DLP) and the Australian Democrats. However in this election both leaders stood successfully for the Queensland House of Representatives seats. Both would have enjoyed a personal following to some degree, in that people voted for the name of the candidate and not the party as such. However the PUP also had a high profile Senate candidate in Queensland-Glen Lazarus, who is a well-known former rugby league player.

While KAP polled higher for the Senate in New South Wales, Victoria, Tasmania and the Australian Capital Territory, it polled higher for the House of Representatives in Queensland, Western Australia and South Australia. Palmer United polled higher for the Senate in Victoria, Tasmania and the Northern Territory but lower for the House of Representatives in those states, achieving instead a better result in the other states, including Western Australia where it eventually had a Senator elected.

The PUP's higher Senate vote in Tasmania could be a result of their high profile candidate, Jacqui Lambie, who won a Senate seat there. She is a former soldier and a single mother who appealed to the Administrative Appeals Tribunal on an issue of military compensation. This may have won her personal support from voters of a similar demographic who may have identified with her. 


\section{Where did PUP/KAP support come from?}

This section of the chapter explores the sources for the votes that flowed to these two parties. Did the votes flow from one party, a few parties or several parties? A useful starting point is the electorate of the leader, Palmer, in Fairfax.

Table 6: Number of votes and swing in electorate of Fairfax, by party

\begin{tabular}{|l|r|r|}
\hline Party & Vote & Swing \\
\hline One Nation & 709 & +0.84 \\
\hline Independent & 1,016 & +1.20 \\
\hline Palmer United & 22,409 & +26.49 \\
\hline LNP & 34,959 & -8.13 \\
\hline Family First & 1,416 & -3.57 \\
\hline ALP & 15,429 & -9.07 \\
\hline Greens & 7,046 & -9.67 \\
\hline Katter Aust Party & 1,623 & +1.92 \\
\hline
\end{tabular}

Source: Australian Electoral Commission.

In Fairfax it appears that the swing to Palmer came roughly equally from the established parties, Labor, Liberal and the Greens, and not from one individual source. However, Labor lost government so the swing against the ALP towards minor parties could be seen as a 'protest vote' against the Labor Government. Also of note in this seat is the very small swing to KAP of less than 2 per cent.

As a comparison the swing in Katter's electorate is indicated in Table 7.

Table 7: Number of votes and swing in electorate of Kennedy, by party

\begin{tabular}{|l|r|r|}
\hline Party & Vote & Swing \\
\hline Palmer United & 6,419 & +7.63 \\
\hline Independent & 571 & +0.68 \\
\hline Greens & 2,727 & -1.25 \\
\hline Katter Aust Party & 24,691 & -17.35 \\
\hline Rise Up Australia & 508 & +0.60 \\
\hline Family First & 1,064 & -0.73 \\
\hline LNP & 34,344 & +14.24 \\
\hline ALP & 13,777 & -3.83 \\
\hline
\end{tabular}

Source: Australian Electoral Commission.

As Katter was a sitting member, his 2013 performance is compared to the result he achieved in the 2010 election. He received fewer votes in the 2013 election, 
suffering a swing against him of 17.63 per cent. Most of that swing went to his LNP rival candidate (14.24 per cent). It would appear the rest of the swing against Katter, along with the swing against the ALP, went in favour of the PUP candidate. A telling point is the significant number of votes won by Palmer's candidate in Kennedy (7.63 per cent) compared to the far fewer votes won by the Katter candidate in Fairfax (1.92 per cent).

In the electorate of Moreton, the sitting Labor member received a small swing in his favour. Most of the swing to KAP (1,070 votes or a 1.30 per cent swing) and to the PUP (4,147 votes or a 5.03 per cent swing) came from other small parties such as Family First and the DLP which did not field a candidate. The swing against the LNP in that seat was -1.16 per cent. The Greens suffered a swing of -5.90 per cent.

Overall, the swing to KAP and PUP did not come from one party (as it did in the case of One Nation) but from a number of parties. In Leichhardt, most of the 8.55 per cent swing to the PUP came from various minor parties, with Labor, Liberals and the Greens suffering swings against them of just over 2 per cent and the Katter candidate receiving a swing in the KAP's favour of 4.29 per cent.

What caused these votes to swing to the two parties? Was it purely a 'protest' against one of the major parties or was the policy of one of the two parties particularly attractive, or was there some other reason? In 2013, Palmer and Katter picked up some of the swing against the ALP and the Greens, but this may not be repeated in the next election and the swing could in fact go back to the major parties. However, some of the votes for KAP and the PUP appear to have come from other minor parties where the minor party did not stand candidates in the 2013 election. Quite likely, these voters searched around for another attractive minor party and settled on either KAP or PUP.

\section{The power of the second preferences}

Minor and micro parties derive some of their power from being able to allocate their second preferences to another chosen party, often determining which side wins the seat. However this power is weakened significantly if the second preferences 'leak' to other parties. There was a significant leakage of PUP second preferences. For example, in the Western Australian seat of Hasluck, 38 per cent of that party's preferences went to the Greens, 27 per cent to Labor and 30 per cent to the Liberals. KAP preferences were also dispersed widely with 30 per cent going to the PUP, 20 per cent to the Liberals as well as 17 per cent going to the Australian Sex Party. By comparison, when the Greens candidate was excluded, 70 per cent of the preferences flowed to Labor and 30 per cent to the Liberals - a much tighter flow of preferences. 
In Franklin, 45 per cent of PUP preferences flowed to the ALP, 42 per cent to the Liberals and 13 per cent to the Greens. Of the KAP preferences, 29 per cent flowed to the PUP, 17 per cent to the ALP, 22 per cent to the Liberals and 14 per cent to the Greens, with 18 per cent going to Family First. Of the Greens preferences, 85 per cent flowed to the ALP and 15 per cent to the Liberals. In the seat of Hinkler, the Greens candidate was excluded first with 49 per cent of preferences going to the ALP, 54 per cent of KAP preferences then went to Palmer United, 28 per cent to the ALP and 18 per cent to the Liberals. PUP preferences were then split with 55 per cent going to the Liberals and 45 per cent to Labor. In the seat of Corangamite, 52 per cent of PUP preferences flowed to Labor and 48 per cent to the Liberals. Greens preferences were divided with 86 per cent going to Labor and 14 per cent to the Liberals. Eighty per cent of Nationals preferences flowed to the Liberals and 20 per cent went to the ALP.

There was a trend across all electorates of KAP and PUP preferences significantly leaking to other parties while Green preferences flowed strongly to the ALP. One reason for this is that the Greens emphasised the importance of its allocation of second preferences, whereas KAP and PUP largely ignored the issue of preference votes in their campaigns.

\section{Conclusion}

In conclusion, the two new micro parties were led by two high profile leaders. However, the Palmer United Party preformed far better than Katter's Australia Party. This is surprising in some ways because Katter had a higher national profile. His policies appealed to his constituency, for example policies to curb the power of the two multinational supermarkets in Australia and low interest loans for farmers. However, Katter was handicapped by a lack of candidates and his poor handling of the same-sex marriage issue. Palmer, on the other hand, stood candidates in every electorate and steered well clear of the same-sex marriage issue, with other policies expressed in very general terms, such as the abolition of tertiary education fees. The swings to both KAP and the PUP did not come from one party alone but from several. These swings even included voters for minor parties whose party stood in the 2010 election but not in the 2013 election - these voters were simply looking for another protest party to express their dissatisfaction with the major parties.

The performance of the two parties varied across Australia. Significantly, both these micro parties only managed to have one candidate elected in the lower house - in both cases their leader in a favourable Queensland seat. In some electorates the level of support for the PUP was very small, in other electorates it was over 20 per cent. In a number of electorates the level of support for KAP 
was less than 1 per cent, whereas in only one electorate did the PUP poll less than 1 per cent. The low percentages of votes, together with the undisciplined leakage of preferences, meant that the potentiality of these parties to influence the eventual electoral outcome was greatly weakened.

Both Katter and Palmer made an impact in the 2013 election, and made some significant gains; they captured attention and captured some of the disaffected vote from the major parties and from other minor/micro parties. However, their campaign management provided much evidence of their inexperience and capriciousness. While Palmer's hastily assembled party did provide voters with a range of policy options and as a consequence did slightly better than the Katter party, whose policies were more imprecise, both were channels for disaffection across regional Australia. Yet both micro parties are tied to the mercurial personalities of their respective leaders. Whether they can follow-up their election campaigns and go on from here to build more credible political movements remains to be seen.

\section{Appendix}

\section{The major policies announced by the two parties}

Clive Palmer and the Palmer United Party announced their policy intentions as follows:

- Abolish the Carbon Tax;

- No increase in taxes and abolition of the mining tax;

- Asylum seekers dealt with quickly on arrival and if found to have a legitimate right to asylum then allowed to enter Australia, and have access to welfare like all other Australians;

- Abolish tertiary fees and Higher Education Contributions Scheme (HECS) payments;

- A nationalised school curriculum and a maximum of 30 students to a classroom;

- Introduction of legislation to require former politicians or senior government officials to have left public office for 10 years before they could work as lobbyists;

- A target for 10 per cent of all vehicles to be running on ethanol-based fuel by the end of 2016, rising to 25 per cent by 2020;

- A full review of Australia's voting system;

- A reduction of 50 per cent in income tax on a second job; 
- An increase in aged pensions, building more nursing homes and making sure people have adequate help so they can continue to live comfortably in their own homes;

- Payment of funding directly to hospitals, circumventing state governments; and,

- Abolition of the fringe benefits tax on business lunches.

The major policies announced by Bob Katter and the KAP were:

- Mandate a national interest test to the privatisation of any public assets;

- Provide an arbitrated price for agricultural produce where farmers request it;

- Restore irrigation water to agriculture in the Murray Darling Basin;

- Mandate ethanol use in Australia, providing structural support to grain and sugar industries;

- Support and extend the Mandatory Renewable Energy Target;

- An overhaul of the current model used to educate Australia's children, with a focus on providing a solid foundation of reading, writing and mathematics, identify great teaching and reward it;

- Stimulate investment in infrastructure, including roads, rail and ports;

- Mandate the allocation of premium shelf space in supermarkets for Australian produce;

- Reduce interest rates and bring down the Australian Dollar; and,

- Support the right of farmers and other citizens to manage their resources and live without 'uninvited interference'.

\section{References}

Horn, Allyson. 2013. 'Big Swing Against Bob Katter in his Seat of Kennedy' . $A B C$ News, 8 September, viewed 20 October 2013: <www.abc.net.au/news/201309-07/big-swing-againts-bob-katter-in-his-seat-of-kennedy $>$.

Houghton, Des. 2013. 'Bob Katter's tolerance of star Senate candidate James Blundell's view on gay unions sparks member exodus'. Courier-Mail, Brisbane, 10 August.

Katter, Robert. 2012. An Incredible Race of People: A Passionate History of Australia. Sydney: Murdoch Books Australia.

Key, Victor, J. 1964. Politics, Parties and Pressure Groups. 5th edn. New York: Thomas Y Crowell. 
McDonnell, John. 2001. 'Beware the Kattermites'. Adelaide Review 215, August: 6-7.

Nowra, Louis. 2013. 'Barramundi Dreaming: The heart and mind of Bob Katter' The Monthly, April: 28-33.

'Palmer Drama'. 2013. Four Corners, television programme transcript, ABC TV, Sydney, 25 November, viewed 3 February 2014: <www.abc.net.au/4corners/ stories/2013/11/25/3896229.htm>.

Palmer United Party. 2013. 'Palmer United Party announces conscience vote on same sex marriage'. Press release, 30 July.

Sadler, Mat. 2011. 'Gay marriage should be ridiculed, says independent Bob Katter'. News.com.au, 16 August, viewed 18 November 2013: <www.news. com.au/national/gay-marriage-should-be-ridiculed-says-independent-bobkatter/story-e6frfkvr-1226116097321>.

Sydney Morning Herald. 2013. 'Bob Katter expects "terrible belting" for his party'. 7 September, viewed 30 October 2014: <www.smh.com.au/federalpolitics/federal-election-2013/bob-katter-expects-terrible-belting-for-hisparty-20130907-2tcc0.html>. 
This text taken from Abbott's Gambit: The 2013 Australian Federal Election, edited by Carol Johnson and John Wanna, published 2015 by ANU Press, The Australian National University, Canberra, Australia. 